\title{
Improved Recovery Demonstration for Williston Basin Carbonates
}

\author{
Quarterly Report \\ October 1 - December 31, 1997
}

\author{
By: \\ Larry A. Carrell
}

Work Performed Under Contract No.: DE-FC22-94BC14984

\author{
For \\ U.S. Department of Energy \\ Office of Fossil Energy \\ Federal Energy Technology Center \\ P.O. Box 880 \\ Morgantown, West Virginia 26507-0880
}

By

Luff Exploration Company

Denver, Colorado 


\section{Disclaimer}

This report was prepared as an account of work sponsored by an agency of the United States Government. Neither the United States Government nor any agency thereof, nor any of their employees, makes any warranty, express or implied, or assumes any legal liability or responsibility for the accuracy, completeness, or usefulness of any information, apparatus, product, or process disclosed, or represents that its use would not infringe privately owned rights. Reference herein to any specific commercial product, process, or service by trade

name, trademark, manufacturer, or otherwise does not necessarily constitute or imply its endorsement, recommendation, or favoring by the United States Government or any agency thereof. The views and opinions of authors expressed herein do not necessarily state or reflect those of the United States Government or any agency thereof. 


\title{
IMPROVED RECOVERY DEMONSTRATION FOR WILLISTON BASIN CARBONATES
}

\author{
QUARTERLY TECHNICAL PROGRESS REPORT \\ Cooperative Agreement DE-FC22-94BC14984--19 \\ Luff Exploration Company \\ Denver, Colorado
}

Award Date: June 10, 1994

Completion Date: December 31, 1997

Government Award: \$1,778,014

\author{
Project Manager: $\quad$ Larry A. Carrell \\ Luff Exploration Company \\ DOE Project Officer: Chandra Nautiyal \\ Bartlesville Project Office
}

Reporting Period: October through December 1997

U.S. DOE Patent Clearance is not required prior to the publication of this document 


\section{IMPROVED RECOVERY DEMONSTRATION FOR \\ WILLISTON BASIN CARBONATES \\ COOPERATIVE AGREEMENT DE- FC22-94BC14984}

\section{Disclaimer}

This report was prepared as an account of work sponsored by an agency of the United States Government. Neither the United States Government nor any agency thereof, nor their employees, makes any warranty, expressed or implied, or assumes any legal liability or responsibility for the accuracy, completeness, or usefulness of any information, apparatus, product, or process disclosed or represented that its use would not infringe privately owned rights. Reference herein to any specific commercial product, process, or service by trade name, trademark, manufacturer, or otherwise does not necessarily constitute or imply its endorsement, recommendation, or favoring by the United States Government or any agency thereof. The views and opinions of authors expressed herein do not necessarily state or reflect those of the United States Government or any agency thereof. 


\section{IMPROVED RECOVERY DEMONSTRATION FOR WILLISTON BASIN CARBONATES}

Contract No. DE-FC22-94BC14984

Luff Exploration Company

Denver, Colorado

Contract Date: June 10, 1994

Anticipated Completion: December 31, 1997

Government Award: \$1,778,014

Principal Investigators:

Mark A. Sippel

Larry A. Carrell

Project Manager:

Chandra Nautiyal

Bartlesville Project Office

Reporting Period: Oct. 1 - Dec. 31, 1997

\section{Executive Summary}

Significant reserve additions have been found by drilling targeted, vertical wells on the flanks of structural features in the Red River where wells on crestal positions have been producing for more than 20 years. Three seismically targeted, vertical wells were successfully drilled to the Red River D zone in Bowman Co., ND. Interpretations of amplitude for porosity and structural position were used to target the drilling locations. The reserves developed as result of drilling three wells, targeting porosity blooms at flank position, appear to be approximately $111,300 \mathrm{~m}^{3}(700,000 \mathrm{bbl})$. There are also partially depleted behind-pipe reserves and five prospective locations which have been identified within the seismic survey areas.

Workshop presentations and a talk at the IPAA annual meeting were made during this quarter. Other technology transfer activity includes development of an Internet site for dissemination of core images and descriptions for Red River and Ratcliffe reservoirs.

\section{Summary of Technical Progress}

\section{Red River Targeted Drilling}

A significant result of this project was the successful application of 3D seismic for identification and exploitation of structural and stratigraphical reservoir compartments in the Red River formation in the southwestern portion of the Williston Basin. At the commencement of this project there had not been a 3D seismic survey in the area for exploration or development drilling. In 1995, the project obtained the first 3D seismic survey with dynamite in Bowman county, ND. The survey was recorded over a cluster of smallfeature reservoirs which had been drilled and producing since 1975. The area of Bowman county, ND and Harding county, SD has been explored for oil accumulations in the Red River formation since 1953. The first oil production in the area was established by drilling on trend, but off structure, from the Cedar Creek anticline using single-point seismic data as a guide for targeting wells. In the 1960's, common depth-point (CDP), 2D seismic technology evolved and allowed exploration for small-area structures at Red River 
depths. Many small, structural features were identified using low-fold, CDP 2D seismic and drilled during the late 1960's and early 1970's. Most of these were developed with one or two wells located at the apparent crest of each structure. During the mid-1980's, it was becoming apparent that the seismic-waveform response was affected by porosity development in the Red River.

Detailed seismic modeling was performed to help predict porosity development in the Red River D Zone. Two wells were drilled in 1996 and 1997 as offsets to a well drilled in 1975 and had produced $58,800 \mathrm{~m}^{3}(370,000 \mathrm{bbl})$ of oil and $19,700 \mathrm{~m}^{3}(124,000 \mathrm{bbl})$ of water. The objective of the development drilling was to test the prediction of porosity from 3D-seismic attribute analysis and the magnitude of off-structure oil reserves.

The computed depth-structure map (shown in figure 1) encompasses one of the features covered by the 3D seismic survey. The original well (Faris 1-22) was drilled near the crest of the feature and penetrated oil productive intervals (relatively thin and with low permeability) in the Red River B, C and $\mathrm{D}$ zones. The structure has about $30 \mathrm{~m}$ (100 $\mathrm{ft}$ ) of relief from the 194-ha (480-acre) base. The seismic modeling shows that increasing amplitude (absolute value) of the seismic trough (normal polarity) below the top of the Red River first reflector is one indicator that porosity and thickness of D Zone are increasing. Overlain on the structure map shown in figure 2 is the distribution amplitude values for the first trough of the Red River event. The distribution and intensity of the trough amplitude suggests that the crest of the feature has low porosity-thickness in the D Zone and that areas of higher porositythickness lie in random patterns along the flanks. In fact, the Faris 1-22 has almost negligible porosity-thickness in the D zone, although it had been perforated and produced down-hole commingled with the $\mathrm{C}$ and B Zones. Two wells were drilled at non-traditional spacing from the Faris 1-22 well to test porosity blooms in the Red River D Zone as indicated from seismic interpretation. Traditional spacing in the Cold Turkey Creek Field has been one well per 129-ha (320-acre) unit. A structural cross-section of the three wells is shown in figure 2.

Drillstem test and production data indicate that the new wells penetrated poorly drained reservoir compartments in the D Zone. A drillstem test of the Red River D Zone at the Faris 1-22 well in 1975 recovered $817 \mathrm{ft}$ of oil and $353 \mathrm{ft}$ of drilling mud. The shut-in pressure was $28,700 \mathrm{kPa}$ (4169 psi) at $2885 \mathrm{~m}$ (9466 ft). The B-27 Muslow-State well recovered $277 \mathrm{~m}$ (909 ft) of oil, $162 \mathrm{~m}(530 \mathrm{ft})$ of water and $67 \mathrm{~m}(221 \mathrm{ft})$ of drilling on drillstem test of the D Zone in October 1996. The shut-in pressure was $26,800 \mathrm{kPa}$ (3893 psi). A drillstem test of the $\mathrm{D}$ zone in the $\mathrm{K}-22$ Pang-Faris well recovered $2140 \mathrm{~m}$ (7022 ft) of oil and $267 \mathrm{~m}(877 \mathrm{ft})$ of water with a shut-in pressure of 24,300 kPa (3528 psi) in June 1997. Drillstem tests in the Red River B Zone at the new wells indicate most depletion had occurred in this reservoir interval as the reservoir pressure was found to be about 13,100 $\mathrm{kPa}$ (1900 psi) at reservoir depth. The original pressure was about $28,300 \mathrm{kPa}$ (4100 psi). Both of the new wells were perforated and acidized in the Red River D zone. A composite production history of the three wells is shown in figure 3 .

The Faris 1-22 was producing $3.2 \mathrm{~m}^{3}$ oil and $2.9 \mathrm{~m}^{3}$ water per day (20 bopd and $\left.18 \mathrm{bwpd}\right)$ at the time the first offset well (B-27 Muslow-State) was completed. The initial production from the B27 Muslow-State well was $24.3 \mathrm{~m}^{3}$ oil and 12.7 $\mathrm{m}^{3}$ water per day (153 bopd and 80 bwpd) during the first month after completion in December 1996. Cumulative production through December 1997 is $7047 \mathrm{~m}^{3}$ (44,323 bbl) of oil. The K-22 Pang-Faris produced an average of $27.2 \mathrm{~m}^{3}$ oil and $7.7 \mathrm{~m}^{3}$ water per day (171 bopd and $36 \mathrm{bwpd}$ ) during the first month after completion in September 1997. Cumulative production from this well is $2951 \mathrm{~m}^{3}(18,559 \mathrm{bbl})$ of oil through December 1997.

The B-27 Muslow-State well penetrated the top of the Red River at a subsea depth which is 10 m (32 ft) low to the Faris 1-22 well. The K-22 Pang-Faris has a subsea depth for the Red River which is $16 \mathrm{~m}$ (53 ft) low to the Faris 1-22 well. While the K-22 Pang-Faris well has the lowest subsea depth for the Red River, it was completed with the lowest water-cut in the D Zone.

Another 3D seismic survey was obtained to the east of the Cold Turkey Creek Field at Grand River School Field in Bowman county, ND. Characteristics of the Red River D Zone from interpretation of the seismic data at the second 3D 
seismic survey were similar to that observed at Cold Turkey Creek. The Red River D Zone produces weak amplitude events at the crest of a structure where an old well had been drilled in 1975 based on structural interpretations from 2D seismic data. The old well has poor porositythickness in the Red River D Zone. The 3D seismic interpretation indicated porosity blooms in random fashion on the flanks of the structure. A new well was drilled approximately $0.95 \mathrm{~km}(0.59$ mile) from the old well in 1997 to test one of apparent porosity blooms which is off-structure from the Winnipeg time map. Reservoir pressure in the D Zone was nearly at original conditions but the Red River B Zone was found to be similarly depleted as at Cold Turkey Creek Field with a pressure of $17,200 \mathrm{kPa}$ (2500 psi) which is drawn down about 10,300 $\mathrm{kPa}$ (1500 psi) from original conditions. The new well at Grand River School Field was completed in the Red River D Zone with an average production of 208 bopd and 56 bwpd during the first month of production.

A significant conclusion reached from the two 3D seismic surveys is that amplitude variation can be successfully used to identify small-area porosity blooms in the Red River D Zone which cannot be predicted from existing well control nor can be accurately mapped with $2 \mathrm{D}$ seismic data. The Red River D Zone is most heterogeneous of the oil-productive zones in the Red River with reservoir targets (resulting from porosity blooms) which are 16 to 32 ha (40 to 80 acres) in areal extent. The Red River B Zone was found to be the most homogeneous reservoir interval with pressure draw-down from older wells occurring across relative great distances. This project has demonstrated that improved recovery from the Red River can be obtained through 3D seismic for identification of Red River D Zone porosity development along flanks of structural features.

\section{Water Injection Test in a Horizontal Well}

Low water injectivity has been a deterrent to initiating waterflood projects in the Red River. To test water injection in a horizontal well, the M$20 \mathrm{H}$ Stearns well was drilled in the Buffalo Field (north area) in Harding Co., SD in December 1996. From testing at the M-20H Stearns well, it is concluded that with a lateral extension of $610 \mathrm{~m}$ (2000 ft) or more, an injection rate of 127 to 159 $\mathrm{m}^{3}$ water per day ( 800 to $1000 \mathrm{bwpd}$ ) should be attainable in the Red River B zone. Based on computer simulation models, this injection rate would result in profitable waterflood projects with one horizontal injection well per $2.6 \mathrm{~km}^{2}$ or 259 ha (1 sq mile or 640 acres). Details of completion and testing of the M-20H Stearns well were discussed in previous quarterly reports.

Luff Exploration received approval in November 1997 from South Dakota regulatory agencies for continued injection at the $\mathrm{M}-20 \mathrm{H}$ Stearns for a period of one year. Injection was resumed in December. It is anticipated that six months of history should provide indications of response at the two offset wells and confirm longterm injectivity.

Technology Transfer

On November 17, a presentation was made at the 68th annual IPAA meeting in Houston:

Emerging Technologies Energy Conference. The 30-minute presentation was entitled "Demonstrating Improved Recovery in Williston Basin Carbonates." The focus of the talk was successful identification and exploitation of structural and stratigraphical reservoirs compartments in the Red River formation in the southwestern portion of the Williston Basin.

Results were shown from a 3D seismic survey and new wells which were targeted using the seismic data.

Four half-day workshop presentations were made in Denver, Colorado and Billings, Montana on November 10 and 14, respectively. The "Red River Study - A Success Story" presentations were made with help from the Rocky Mountain Region Petroleum Technology Transfer Council. These workshops were designed for individuals and independent operators who are interested in exploration and development of Red River reservoirs in the southwestern portion of the Williston basin. The workshop covered reservoir characterizations from an integrated perspective of geology, engineering and seismic disciplines. Results from horizontal and vertical wells were presented as examples of reserve additions that are possible by primary and secondary in mature fields in the southwestern portion of the Williston Basin.

An Internet website was developed for 
dissemination of core and petrographic data from the Red River reservoirs of Bowman county, ND and Harding county, SD. A similar website was developed for Ratcliffe reservoirs in Richland county, MT. These websites provide access to quality photographs with descriptions of core from these reservoirs. High-resolution images may be downloaded with descriptions, porositypermeability and log data from these sites after previewing low-resolution samples. These sites will be available in February 1998 and will be located under the Rocky Mountain Region of the Petroleum Technology Transfer Council home page. Visit http://www.pttc.org and then connect with the page for the Rocky Mountain Region. 


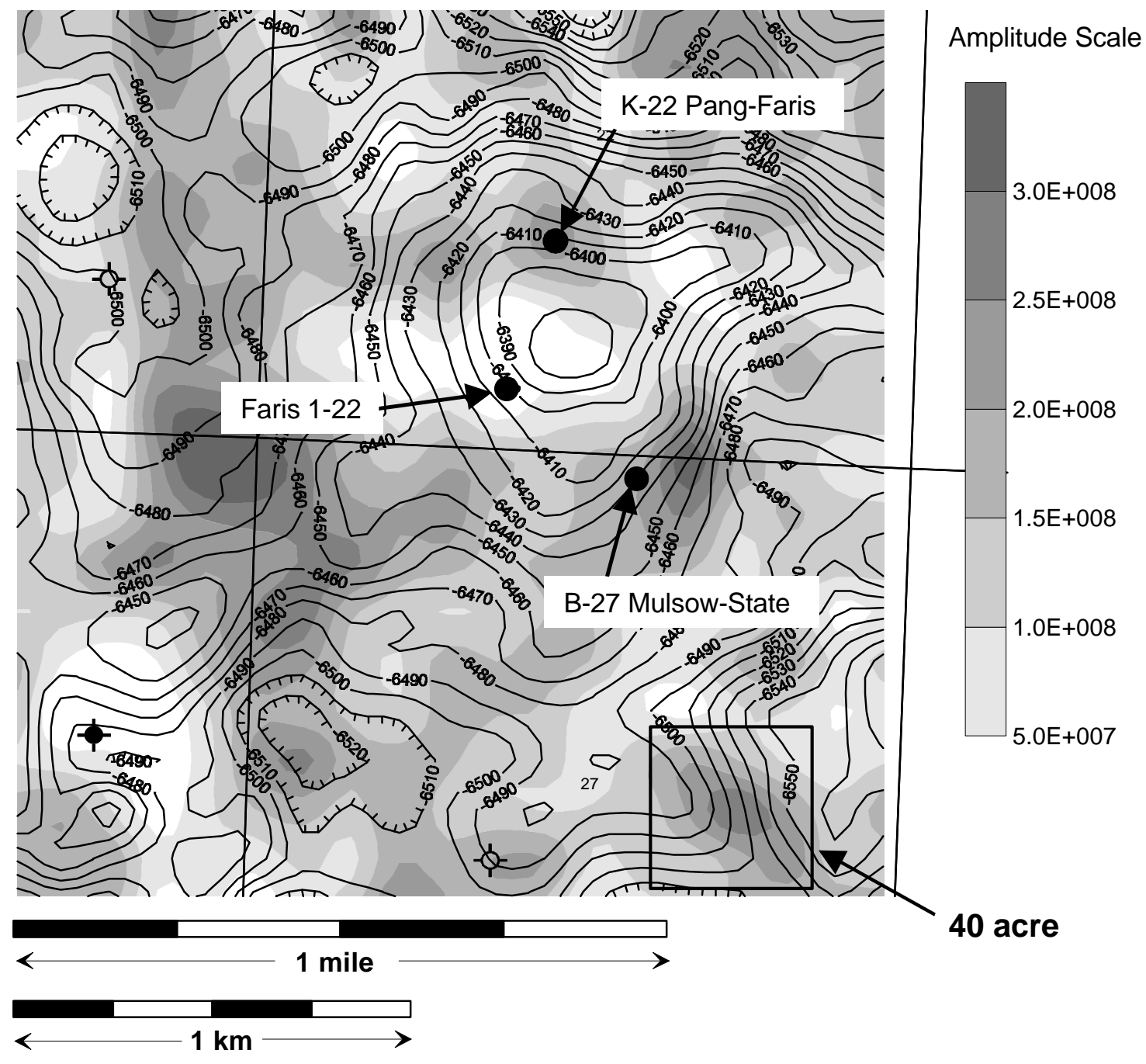

Figure 1: Computed Red River depth structure with T1 amplitude (reversed). Dark shading indicates stronger amplitude response and greater porosity-thickness in the Red River D Zone. 


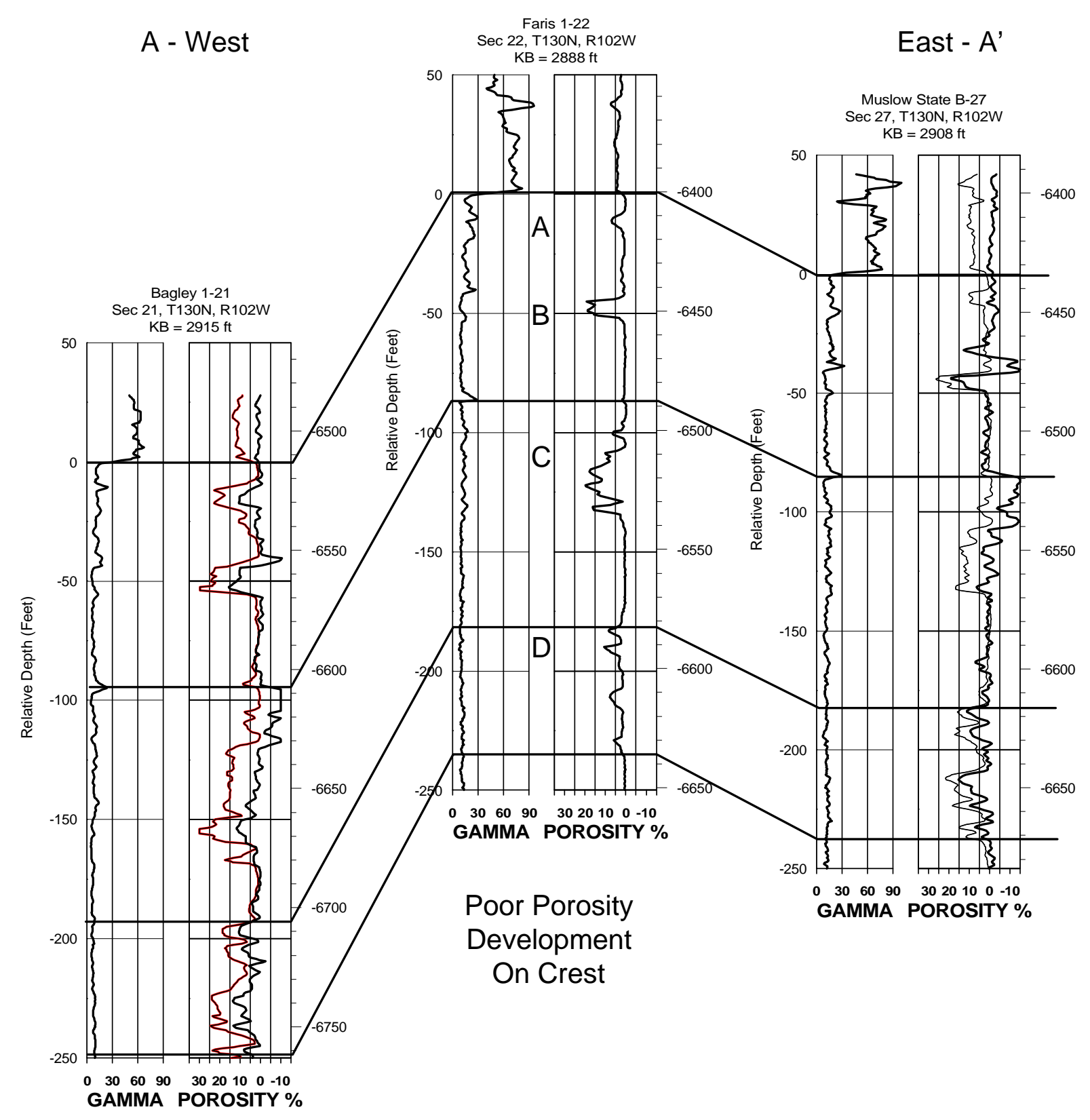

Figure 2: Structural cross-section of Red River at the structure within Cold Turkey Creek Field shown on figure 1 . The crestal well has thin intervals and poor porosity. Flank wells have thicker intervals and better porosity. 

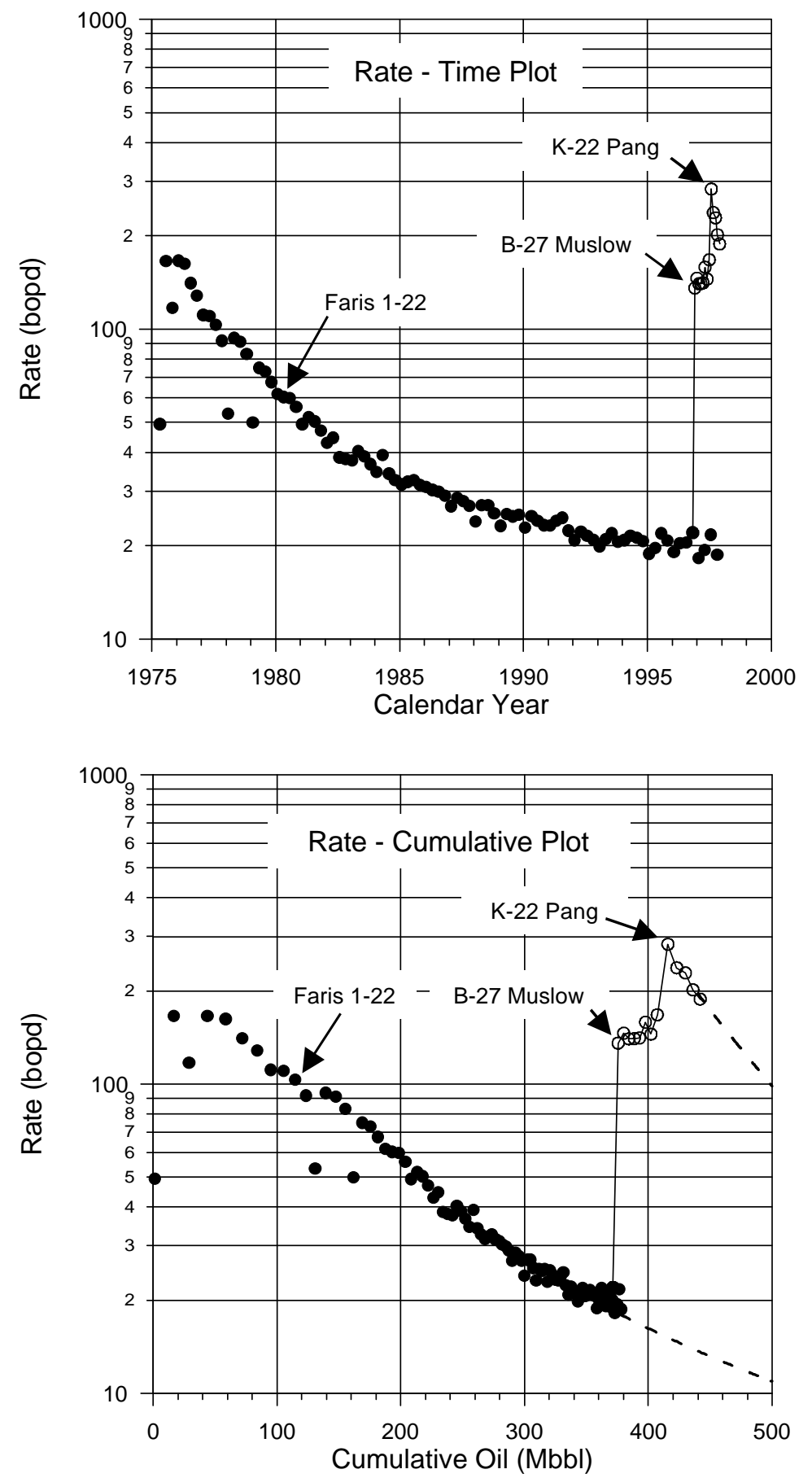

Figure 3: Composite production history from the Red River at the structural feature in Cold Turkey Creek Field shown on figure 1. 